\title{
The Fall of Icarus: the Paradox of the Ottoman Centralization and the Abstraction of Timars
}

\author{
Muhsin Soyudoğan \\ Department of Sociology, Gaziantep University, Turkey \\ soyudogan@gmail.com
}

\begin{abstract}
In the decades following the conquest of Constantinople the Ottoman administrative and military system underwent a major reorganization in the direction of centralization. The effort to some degree assured the state control over the feudal-like timar system and gave it its exceptional characteristic. However, the same endeavour in the long run made the state lose control over vast agricultural production. It was a paradox of centralization which made the Ottoman state firm but fragile.
\end{abstract}

\section{Keywords}

Vidin - Vulchitrin/Vučitrn - inspection of 1487 - timar ruznamçe - timar tracking land-oriented timar - value-oriented timar

The Ottoman political thought on the relation between state and people was formulated by what was called the circle of justice, which meant that in order to hold state power there needed to be a highly developed hierarchal militarybureaucratic organization; which would not come true unless accompanied by a well-structured economic organization. Thus, the continuity of state power depended on the economic satisfaction of its main agents, i.e. the soldiers and other civil servants. The problem, however, was how the revenues would be distributed among them. There were two possible ways; either revenue could be collected and then distributed among incumbents or they could be allowed to collect the revenue for their own sake. The first method became the full scale

* I convey my special thanks to Douglas Howard, the anonymous referees and the editors of Turkish Historical Review for their comments and contributions. 
mode of economic redistribution only after the development to a certain level of modern communication and transportation technologies. In the Ottoman empire, this method had already been used to feed and equip a well-developed bureaucracy and central army, consisting of the cavalry corps, named altı bölük halkı (six divisions of cavalry), and the infantry corps, called janissaries. These two elements were formed to create a balance between the Ottoman family, or central government, and local families, or the provincial army. While the central army and bureaucracy received a salary called ulufe, ${ }^{1}$ local warlords and the provincial army (called timariots or timarli sipahis) were granted revenue sources, especially land cultivated by peasants, under the name of dirlik or timar. $^{2}$ That is, economic resources were divided into two main parts, those directly supervised by the central treasury and those left to the provincial cadres. Thus, the Ottoman empire rose upon a balance of power set between the central army and provincial army, which historians usually rate as the two pillars of the Ottoman socio-political structure. ${ }^{3}$ Nevertheless the tension between these two realms never ceased, and which resulted in the transformation of the Ottoman mode of economic distribution and the administrative organization. Therefore, any attempt to evaluate the Ottoman timar system needs to focus on this balance and the tendency to disturb it.

The issue of resource distribution can be discussed in relation to the different spheres of the Ottoman empire's socio-economic structure in the sixteenth century. ${ }^{4}$ In each sphere, the mode of ownership, the relations of production, and the control mechanism over production were varied. In what can be called the bureaucratic sphere, the revenues called mukataa, or the imperial revenues (havas-ı hümayun), were directly supervised by the central bureaucracy and their agents in provinces. This sphere was totally under the control of the sul$\tan$ (the state). Any surplus used for the payments of the central cadres or for the expenses of military campaigns and defense was managed in this sphere. On the other hand, in what can be called the military sphere, the supervision

1 Ulufe was a type of salary fixed at certain rates per diem but paid in cash every three months.

2 A timar consisted of annual taxes in cash and in kind mostly paid by agricultural producers.

3 Leopold Von Ranke was one of the first historians who drew attention to the importance of the timar system in the nineteenth century, and created a schema for the basis of the Ottoman empire consisting of the sultan, the janissary, and the timar system, von Ranke, Leopold, The Ottoman and the Spanish Empires, tr. Walter K. Kelly (London: Whittaker and Co., Ave Maria Lane, 1843). p. 5. Of the three elements, the timar system has been one of the most studied topics by Ottomanists. Historians who usually study the pre-seventeenth century unavoidably noted the system, yet few described the system in all its dimensions, as did Ömer Lütfi Barkan in Türkiye'de Toprak Meselesi: Toplu Eserler 1 (İstanbul: Gözlem Yayınları, 1980).

4 Soyudoğan, Muhsin, "Reassessing the Timar System: The Case Study of Vidin (1455-1693)", Unpublished Ph.D. Dissertation, İhsan Doğramacı Bilkent Univeristy, 2012, p. 59. 
and possession of revenues called dirliks (grants, livelihood), i.e. hass, zeamet and timar, were given as tenures mostly to provincial cadres. What we call the timar system comprised all the economic organization and relations of productions in the military sphere. From the very beginning of its foundation the Ottoman state had always strived to consummate a control mechanism over the military sphere so as over the timar system. As a matter of fact, it succeeded to a certain extent. However, this control faded away through a process which in this paper I refer to as the "abstraction of timars".

The Ottoman empire's emergence as a superpower of the pre-modern age due to its rapid expansion over neighboring lands is usually evaluated by historians through a religious and state-centric approach, i.e. the Ottoman state harnessed by the Islamic ideal of gaza or jihad devoted itself to a religious war over Christianity. ${ }^{5}$ Then they summarize the process of resource distribution as that the Ottoman government conducted surveys in newly conquered lands and then distributed newly explored economic resources among state servants, especially the military. ${ }^{6}$ However, conquest is a dual faceted phenomenon and the Ottoman entity was not a homogenous and monotype power. Rather, it consisted of at least two different bodies of power. The Ottoman central government always had to cooperate with powerful families or other power holders to exert its power over neighboring territories. The power holders might either be Ottoman statesmen and tribesmen, or ex-"enemy" warlords changing sides. Usually, in the fourteenth and fifteenth centuries the newly conquered lands were initially left to power holders who formed almost autonomous states. Then through centralization policies, the lands were gradually timarized, i.e. distributed among warriors who were directly linked to the central state or hassified, i.e. confiscated by the central state to pay the salaries of central cadres or for other state expenses. That is to say, economic distribution and redistribution occurred in two steps: first, among the centrifugal power holders, and second, between them and the central state. The important point in this process is that the Ottoman attempt at centralization failed due to structural problems when the central government exerted its power over a vast territory. Eventually, the center began unwittingly producing new centrifugal powers who would challenge the center.

5 Paul Wittek, pioneered this theory. Wittek, Paul, The Rise of the Ottoman Empire (London: The Royal Asiatic Society, 1938). This idea was adopted by many scholars, such as Halil İnalcık, Osmanlı İmparatorluğu Klâsik Çă̆ (1300-16oo), tr. Ruşen Sezer (Istanbul: Yapı Kredi Yayınları, 2003). p. 9 .

6 Acun, Fatma, "Klasik Dönem Eyalet İdare Tarzı Olarak Timar Sistemi Ve Uygulaması", in Türkler, ed. Hasan Celal Güzel, Kemal Çiçek, and Salim Koca (Ankara: Yeni Türkiye Yayınları, 2002). p. 901. 
This struggle on resource distribution prompted the state to create one of the most sophisticated bureaucratic systems of the pre-modern age. The Ottoman bureaucracy embodied a quite advanced filing system keeping the data from surveys conducted at certain intervals. For example, when the government decided to impose the timar system over a territory or to extract the economic revenue from a certain region on behalf of the central state a survey was conducted to record every kind of taxable economic activity. The details of the people, animals, goods, and economic activities considered taxable, as well as those who would be granted some of the taxes, were recorded in a ledger called mufassal defter. Then, the timar possessors and their revenue sources were succinctly recorded in the icmal (or mücmel) defter, which was also used to track timars as they changed hands over time. At the end of the fifteenth century another type of ledger was compiled, called timar ruznamçe defteri or simply ruznamçe. Creating a far more efficient system to track timars, this new genre of defters recorded timar transactions in a very detailed way.

There are thousands of volumes of these defters in the Ottoman archives. Starting in the 1930s these sources have been utilized to draw a picture of the Ottoman economic, demographic, ethnic and military situation. These studies have laid the foundation of a better understanding of the timar system, revealed what the system looked like and its operation during its heyday spanning roughly from the mid-fifteenth to the end of the sixteenth century. The problem with this traditional approach to the system is that it creates an image of a static institution that is; it barely touches upon the transformation of the timar system over time. Rather, it is broadly described as a system that was inherited from a Greek or a Turko-Islamic tradition at the very beginning of the formation of the Ottoman state, refined in the sixteenth century and eventually began to degenerate in the last decades of that century. This superficial and problematical view portrays that once the timar institution operated perfectly however began to degenerate because of impotent sultans or statesmen, and moral collapse and public unrest caused by demographic boom and economic downturn, and economic and technological developments in the western world. ${ }^{7}$ Therefore, any serious change in the system tends to be associated with a number of external factors. Even though such an external causational approach cannot be totally ignored, this paper tries to offer an internal, paradoxical approach, which attributes the degeneration to the nature of the system itself. In other words, historians usually tend to over-identify the timar

7 For brief details on the problem see, Dikici, Mehmet, Feodalizm, Mülkiyet ve Türk Toprak Sistemi (İzmir: Hür Efe Matbaası, 1996), pp. 384-5; Cin, Halil, Mirî Arazi ve Bu Arazinin Mülk Haline Dönüşümü (Ankara: Ankara Üniversitesi Hukuk Fakültesi Yayınları, 1969), pp. 78-9. 
system with its most efficient phase in the mid-sixteenth century, and therefore confuse tautologically symptoms of degeneration with its causes. However, as this paper shows, in fact the problems of the timar system were brought about by the very factors that made it a strong institution and the other factors were only aggravated the situation.

This paradox has been barely touched by Ottomanists, mainly due to the adopted methodological approaches. First, an actor-based view was inherited from the intellectual environment of the late sixteenth century, ${ }^{8}$ according to which individuals, especially decision makers, can be taken as responsible for both success and failure. Thereby, they were capable or incompetent statesmen who allegedly boosted or hindered the Ottoman power, respectively. As a result, there was purported to be an ideal state or a golden age in which, like all other institutions, the timar system existed in its 'original' and 'pure' form. Having created this image, any kind of diversion from this ideal type assumed to be the potential degeneration of the system. Secondly, after the 1930 s under the influence of the Annales School, more or less a structuralist perspective dominated Ottoman historiography and Ottomanists initiated a demographic, economic and social history. However, the analytical and theoretical weakness resulted in most works being purely descriptive or else transliterations of archival materials. Usually historians prepared some descriptive statistical graphs and figures based on one or two ledgers, especially mufassal and icmal defters. In return, that limited historians' works in both the geographical and temporal sense. As a result, a new genre of sancak studies ${ }^{9}$ dominated Ottoman studies on defters. These studies appeared as athematic and eclectic works that focus on almost every detail about a certain geographical area.

Another body of problems is related to the way in which archival sources were used. The defterologists ${ }^{10}$ often ignored the relations between different types of sources and the need for a systematic analysis of them. Nor they fully grasped the true nature of each source and consequently omitted the transformation of the timar system and Ottoman administration. While many works utilized the mufassal and icmal defters, the later type of defter, the

8 For a detailed review of such Ottoman intellectuals see, Öz, Mehmet, Osmanlida Çözülme ve Gelenekçi Yorumcuları (İstanbul: Dergâh Yayınları, 1997).

9 For a bibliographic review of such studies see, Gürbüz, Adnan, XV. XVI. Yüzyll Osmanlı Sancak Çalı̧maları:Değerlendirme ve Bibliyografik Bir Deneme (İstanbul: Dergâh Yayınları, 2001).

10 Defterology is accepted by historians as a special field, which had its own terminology and methods, in Ottomans studies. Lowry, Heath W., Studies in Defterology: Ottoman Society in the Fifteenth and Sixteenth Centuries (Istanbul: IsIs Press, 1992); Acun, Fatma, "Osmanlı Tarihi Araştırmalarının Genişleyen Sınırları: Defteroloji”, Türk Kültürü İncelemeleri Dergisi, 1/1 (1999), 319-32. 
timar ruznamçes, did not adequately draw the attention of historians. In fact, the timar ruznamçe defters are not only crucial for studying the timar system in the post-survey period, roughly from the late sixteenth to the nineteenth centuries, but also for being complement to the icmal defters produced after the 148 os. This last point is important because not all the icmal defters survived to the present day. Thanks to ruznamçes we can recover to certain extent the data of a certain survey even if ledgers are fragmented, damaged or totally lost. It is a basic rule of methodology that the chosen sample is an important determinant of the validity and reliability of the research, and the most complete, or the larger, sample, containing more varieties, provides a better result. In the light of this, the current study tries to use different types of defters to form time series data of certain intervals. Moreover, it tries to contribute to our inquiry about the timar system by making a systematic comparison of the two Ottoman regions namely Vidin ${ }^{11}$ and that of Vulçitrin (Vučitrn). ${ }^{12}$

Although it can be argued that this sample does not reflect sufficient geographic variety since both sancaks were located in the Balkans, there are two reasons for restricting the scope of study to these sancaks. First, they provide relatively better samples than any other sancaks. Though it is estimated that the Ottomans conducted surveys from an early period of the formation of the state, the earliest extant defter prepared based on such a survey is dated $1432,{ }^{13}$ and furthermore, from the following two decades only several

11 The Sancak of Vidin corresponded to a region consisted of today's Bulgarian Vidin and Montana and Serbian Bor and Zajecar. Some of the works on the Sancak of Vidin are Bojanić, Dušanka, Видин и Видинският санджак през 15-16 век: Документи от архивите на Цариград и Анкара [Vidin and the Sancak of Vidin in the $15^{\text {th }}-16^{\text {th }}$ c.: Documents from the Archives in Istanbul and Ankara] (Sofia: Nauka i Izkustvo, 1975); Bojanić, Dušanka, Фрагменти опширног пописа Видинског санџака из 1478-81. године. [Fragments from the detailed inventory of the sancak of Vidin from 1478-81] Мешовита грађа (Miscellanea), 2 (1973), 79-177; Bojanić, Dušanka, Фрагменти збирног пописа Видинског санџака из 1466. године. [Fragments from the aggregate inventory of the sancak of Vidin from 1466] Meshovita Gradja (Miscellanea), 2 (1973), 5-77; Bojanić, Dušanka, Турски закони и законски прописи из XV и XVI века за Смедеревску, Крушевачку и Видинску област. [Turkish laws and legal regulations from the $15^{\text {th }}$ and $16^{\text {th }}$ centuries about the regions of Smederevo, Krushevac and Vidin] (Beograd: Istorijski Institut, 1974), Kayapınar, Ayşe, Le sancak ottoman de Vidin du XV è à la fin du xvie siècle (Istanbul: Les Éditions Isis, 2011).

12 Located in the modern day northeastern regions of the Republic of Kosovo, especially around Pristina and Mitrovice. See, Hadžibegić, Hamid, Adem Handžić and Ešref Kovačević, Oblast Brankovića. Opširni katastarski popis iz 1455. Godine (Sarajevo : Orijentalni institut, 1972).

13 İnalcık, Halil, Hicrî 835 Tarihli Sûret-i Defter-i Sancak-i Arvanid (Ankara: Türk Tarih Kurumu Yayınları, 1954). 
fragments of defters survived. ${ }^{14}$ For the most part the earliest defters housed in various archives are mainly outputs of surveys undertaken from the 1450 s to the 1580 . In these two sancaks we have a reasonable number of defters providing data from almost all the surveys conducted in this period. Secondly, these two sancaks offer insight into two distinct worlds, with Vidin being historically a frontier region and Vulçitrin being relatively an interior region. In this sense the sample reflects, to a certain degree, a variety in geography, climate and socio-economic life as well.

Constructing a time series is important for undertaking a comprehensive analysis of quantitative data on the population, settlement patterns, revenue sources and revenue distribution. However, this data can be misleading unless it is elaborated with qualitative data ${ }^{15}$ that provides information about the nature of the sources, the timar system, and the Ottoman administrative organization. In this respect, I employ here a method that I call "timar tracking" that allows the data to be hybridized. To explain this method, let us suppose that there two defters from different points in time. The first defter records ten householders while the second one contains 20. From a basic comparison, it would seem that the population has doubled in this period. However, this increase might be related to an administrative change, or it might result from differentiation in methods of inspection, or from changes in socio-economic policies. It was not unusual for the borders of sancaks to be changed, for the Ottoman inspectors not to be equally attentive in all surveys, or for certain groups to be exempted from taxes in one period whereas in another time span to be recorded as taxpayers. For that reason, it is important to reconsider the nature of the defters and the extent of their value as sources.

Timar tracking is a method based on the principle of searching in later defters for a specific timar that was recorded in an earlier defter. This method is much more comprehensive than comparing statistical data obtained from two or more defters. Timar tracking tries to overlap the aim of the researcher and that of the Ottoman state in conducting surveys and recording timars and $t i-$ mar transactions. The Ottoman state employed a colossal administrative body to track timars in order to control and develop new policies in relation to economic re/distribution. Now, a historian can utilize that tracking system to see the degree to which the state was in control, and what policies the government

\footnotetext{
14 These fragments were recently published. See, İnalckk, Halil, Evgeni Radushev and Uğur Altuğ, 1445 Paşa Livâsı İcmâl Defteri (Ankara: Türk Tarih Kurumu Yayınları, 2013).

15 Sometimes a seemingly unimportant sign can be crucial to solving an important question. The terminology that was used or the way that a defter was organized can give important clues about the system.
} 
developed for the timar system, thus revealing how the timar system was transformed over the years.

\section{Land-Oriented Timar}

In his article on timar in Encyclopaedia of Islam Jean Deny defined timar as "a grant of land for military service (beneficium) or, more exactly, a kind of Turkish fief, the possession of which entailed upon the feudatory the obligation to go mounted to war (sefere eshmek) and to supply soldiers or sailors in numbers proportionate to the revenue of the appanage (dirlik)". ${ }^{16}$ In the second edition this time Halil İnalclk authored the article, defining it as "nonhereditary prebends to sustain a cavalry army and a military-administrative hierarchy in the core provinces of the Ottoman Empire". ${ }^{17}$ At first glance, these two definitions seem more or less the same; however, the words they choose reflect a rooted dichotomy about the issue in the Ottoman historiography. Many Western scholars and Orthodox Marxists tended to associate the timar system with "western feudalism". ${ }^{18}$ Therefore, a timar was simply a matter of land ownership. Ottoman nationalist or statist historians object to almost any idea that relates any Ottoman institution with a non-Islamic one. ${ }^{19}$ For them, as a sui generis institution the timar system has nothing to do with feudalism nor any mode of production set forth in Marxist literature. Rather timar was simply a prebend or tenure giving the right to collect taxes appropriated from economic resources owned by the state for one's own use. ${ }^{20}$ More precisely, timar was the name of special revenue of less than 20,000 akçes. ${ }^{21}$

16 Deny, Jean, “Timar", in Encyclopaedia of Islam, First Edition (1813-1936), ed. M. Th. Houtsma, T.W. Arnold, R. Basset and R. Hartmann, vol. IV (Leiden: Brill, 1927). p. 767.

17 İnalcık, Halil, "Timar", in Encyclopaedia of Islam, Second Edition [hereafter $E I^{2}$ ], ed. H.A.R. Gibb et al. (Leiden: Brill, 1960-2006), p. 502.

18 For example see, Moutafchieva, Vera P., Agrarian Relations in the Ottoman Empire in the 15th and 16th Centuries (Boulder, New York: Columbia University Press, 1988). p. 1. Also see the discussion on the issue in Şanda, Hüseyin Avni, Reaya Ve Köylü (İstanbul: Habora, 1970).

19 As a typical example see, Mehmet Fuat Köprülü, Bizans Müesseselerinin Osmanlı Müesseselerine Tesiri (Ankara: Akçă̆, 2004).

20 In another article Inalclk warned that the timar is not something about bestowing land or certain rights over land. İnalcık, Halil, "İslâm Arazi ve Vergi Sisteminin Teşekkülü ve Osmanlı Devrindeki Şekillerle Mukayesesi”, in İnalcık, Halil, Osmanlı İmparatorluğu: Toplum ve Ekonomi (İstanbul: Eren, 1996). p. 27.

21 For a comprehensive definition of timar see, Barkan, Ömer Lütfi, "Timar", in Türkiye'de Toprak Meselesi: Toplu Eserler 1 (İstanbul: Gözlem Yayınları, 1980). p. 805. 
Contemporarily it is hard to find any discussion concerning whether the timar system was a feudal system; rather, as the studies on defters proliferated, historians have been persuaded by the second definition. In fact neither definition is wrong, but they are not sufficient, either. Feudalists deductively approach the issue and define the timar in the light of well-constructed theoretical frameworks. On the other hand, prebendalists inductively focus on the institution and define the timar based on the law codes and research on the defters. The main problem in the feudalist approach is that, instead of adapting the theory to the Ottoman reality, or revising it based on new conditions, these intellectuals tried to adapt reality to the theory. ${ }^{22}$ However, the main problem of the prebendalists' approach is that they too greatly idealize the sixteenth century and overemphasize the function of state in the timar system. As a matter of fact, defining something always contain the risk of freezing the signified and reflecting as an ahistorical entity. Likewise, both definitions conceptualize the pre-seventeenth century timar system as something static and immune to change. On the contrary, the timar system was a dynamic institution, historically transformed through a process of abstraction i.e. transformed, from more private spaces, for example the fief, into state-controlled values, an example of this being the prebends.

To open the discussion on the nature of timar it is necessary to answer the question of whether a timar was a unit of land (physical timar) or unit of revenue (fiscal timar). One way to answer this is by looking at the Ottoman law codes (kanunname) or turning to Islamic sharia law. In this case, it can be claimed that the land within the Ottoman realm belonged to the state, and only if the sultan gave permission could there be such a thing as private property. That is to say, the state owned everything and gave nothing but the right to collect taxes to the timar holders. The judicial dimension of a phenomenon, however, needs not necessarily be in line with reality. Laws might sometimes be constructed only as legitimation for an ideology, or may represent more of an ideal than a fact. Historians who set a premium on the state in their analysis may tend to overlook this truth. ${ }^{23}$ More than that, even if we were to accept

22 Exceptionally, some scholars tried the opposite. For them what was dominant in Ottoman economic relations was not feudalism but the Asiatic Mode of Production. This idea was fiercely criticized by feudalists. For example see, Divitçioğlu, Sencer, Asya Üretim Tarzı ve Osmanlı Toplumu, Marxist Üretim Tarzı Kavramı (Istanbul: Türkiye İş Bankası Yayınları, 2010).

23 Halil Berktay calls such approaches "narrow legal-formalist", in Berktay, Halil, Kabileden Feodalizme (Istanbul: Kaynak Yayınlanı, 1983). pp. 299-300. 
that the laws did perfectly portray the facts, there is the further problem that these laws were mostly codified in the sixteenth century, and they are open to ahistorical generalizations.

A better way to answer the question is to look at the timar records and track them as vigilantly as possible. Table 1 shows a timar recorded in Vulchitrin from 1455 to 1487 . The timar remained the same from 1455 to 1485 in terms of its constituent territories except for one village that disappeared from the records and then in 1487 was divided into two different timars. Doğancı Yusuf enjoyed the timar for more than 28 years, until 1482 when he retired and his timar was given to Mustafa and his brother Mehmed. ${ }^{24}$

Table 2 shows a similar case in Vidin, in which a timar also remained in the possession of the same person for a long period; Bedir possessed this timar

TABLE $1 \quad$ A Timar in Vulçitrin.

\begin{tabular}{lrrrr}
\hline & Doğancı Yusuf & $\begin{array}{l}\text { Mustafa and } \\
\text { Mehmed }\end{array}$ & $\begin{array}{l}\text { Evrenuz / } \\
\text { Oruç }\end{array}$ \\
\hline Production Place & $\mathbf{1 4 5 5 ^ { 2 5 }}$ & $\mathbf{1 4 7 7 ^ { 2 6 }}$ & $\mathbf{1 4 8 5 ^ { 2 7 }}$ & $\mathbf{1 4 8 7 ^ { 2 8 }}$ \\
\hline Village of Pavlofçe & 2,766 & 1,341 & 1,647 & 2,266 \\
Village of Dolne İvrelani & 918 & $\mathbf{1 , 0 4 2}$ & 877 & $\mathbf{1 , 5 4 4}$ \\
Village of Gorne İvrelani & 560 & 712 & 1,237 & 787 \\
Village of Bobofçe & 585 & 794 & 822 & 1,723 \\
Village of Şaykofçe & $\mathbf{1 , 2 3 8}$ & 670 & 914 & $\mathbf{1 , 0 7 4}$ \\
Village of İvladofçe & 3,459 & 3,125 & 3,858 & 4,734 \\
Village of Çernovrinçe & $\mathbf{1 , 1 9 9}$ & 941 & $\mathrm{X}$ & $\mathrm{X}$ \\
Total & $\mathbf{1 0 , 7 2 5}$ & $\mathbf{8 , 6 2 5}$ & $\mathbf{9 , 3 5 5}$ & $\mathbf{6 3 2 0}+5 \mathbf{5 0 8}$ \\
& & & & \\
\hline
\end{tabular}

\footnotetext{
24 "Tekaüd-i ihtiyar ettigi sebebden Mustafa'ya virildi. Fi cemazielahire sene 887", Başbakanlık Osmanlı Arşivi [hereafter вОА], тт.d 1081/1 (icmal) (Vulçitrin), p. 37.

25 воА, тт.d 2M(mufassal) (Vulçitrin), pp. 456-459.

26 воА, тт.d 1048 (mufassal) (Vulçitrin), pp. 251-5; воА, мAD.d 16 (icmal) (Vulçitrin), p. 26; воА, тт.d 1081/1, p. 37 .

27 воА, тт.d 9 (mufassal) (Vulçitrin), pp. 258-62; воА, мAD.d 97 (icmal) (Vulçitrin), pp. $37 \mathrm{~b}-38$.

28 воА, тт.d 22 (icmal) (Vulçitrin), pp. 51-2.
} 
until 1482, when his children Musa and Ali inherited it. ${ }^{29}$ When the timar of Bedir is tracked, it can be seen that his timar was also almost fixed in term of spatial dimension. It can be seen below that the last two mezra' $a \mathrm{~s}^{30}$ were not recorded in the 1455 defter. This is because of the instability in production during that time in Vidin. As a frontier sancak, Vidin was frequently attacked by "enemy" forces. The survey of 1455 was conducted immediately after an invasion in $1454 \cdot{ }^{31}$ Consequently, in this period, production remained low and some places were not even recorded. In 1481, Vidin was hit by another raid, which ruined many settlements. ${ }^{32}$ This explains the reason why all but the first village were retitled as mezra' $a$ (uninhabited) in the 1483 survey.

TABle 2 A Timar in Vidin.

Bedir, son of Hizır

Musa \& Ali, sons of Bedir

Production Place

$1455^{33} \quad 1466^{34} \quad 1479^{35} \quad 1483^{36}$

\begin{tabular}{lrrrr}
\hline Village of Ustobil & 2.711 & 4.010 & $?$ & 4.123 \\
Village of Sumarin & 120 & 120 & $?$ & - \\
Village of Dolne Leşniçe & 60 & 60 & $?$ & - \\
Village of Batna & - & - & $?$ & 100 \\
Mezra'a of Hlabinçe & $\mathrm{X}$ & - & $?$ & - \\
Mezra'a of Gruniçe & $\mathrm{X}$ & - & $?$ & 100 \\
Total & 2.891 & 4.190 & 5.661 & 4.323 \\
\end{tabular}

29 It is not certain whether he died or retired but a small note on the defter states that Musa and Ali received the timar of their father Bedir in 1482, BOA, MAD.d o1 (icmal) (Vulçitrin), p. 25b.

30 This is a term usually used for unpopulated or periodically populated settlements where agricultural production took place. İnalcık, Halil, “Mazra'a”, in $E I^{2}$, X (1991).

31 See Preface by Vera Mutafčieva, in Bojanić, Dušanka, Видин и Видинският санджак през 15-16 век: Документи от архивите на Цариград и Анкара [Vidin and the Sancak of Vidin in the $15^{\text {th }}-16^{\text {th }}$ c.: Documents from the Archives in Istanbul and Ankara], p. 5 .

32 Soyudoğan, "Reassessing the Timar System: The Case Study of Vidin (1455-1693)", p. 183.

33 İstanbul Büyükşehir Belediyesi Atatürk Kitaplı̆ğ [hereafter і в вAк], мС.YZ.o 9o, p. 30.

34 BOA, MAD.d 18 (icmal) (Vulçitrin), p. 5 b.

35 BOA, MAD.d 01, p. 25b. We have no any remnant of defters from this survey. This is why we do not know the amount of revenue that each village produced.

36 BOA, MAD.d o1, p. 25b. 
Indeed, not all timar lands were kept unified; nevertheless in terms of constituent lands a great majority of timars either changed only slightly or did not change at all in the period between 1455 and 1487. On that sense a timar referred to a land unit i.e. a group of production places. However, after this period, the border of timars changed with every new survey. Each time a certain production place regrouped with new places to form a timar. So it was no more possible to track the same timar throughout several surveys as it done in above examples. In this way, the timar began to lose its character as a land unit after the reign of Bayezid II (1481-1512).

This change raises the question of what happened in this period to alter the character of the timar. From 1455 until 1490 five surveys were conducted in Vidin and Vulçitrin, indicating that these regions were surveyed approximately every seven years. ${ }^{37}$ In the following 90 years, however, these regions were surveyed approximately every 18 years. Surveys were important in controlling and managing economic resources and their redistribution. Yet, this does not mean that the state became less eager to monitor the timars. Rather, it was possible for the state to conduct fewer surveys while, with newly developed techniques, still able to manage more efficiently the process of timar tracking.

During the reign of Bayezid II two significant changes appeared in mufassal and icmal types of defters. First, the style of script changed; the previous Persian style ${ }^{38}$ was replaced by an authentic Ottoman style. ${ }^{39}$ The second change was related to the side notes contained in the icmal defters. These notes, written on each record, showed when and why a certain timar changed hands in the period between two surveys. After conducting a survey scribes used to prepare two different icmal defters: the defter-i icmal or defter-i mücmel and suret$i$ defter (copy). ${ }^{40}$ These defters recorded all grants allocated during a survey

37 From the existing defters it is known that a survey was conducted in Vidin between 1483 and 1515, but we do not know the exact year. Since these two regions were surveyed almost in the same years each time, the estimated date of the missing survey of Vidin was around 1487. Also there was a missing survey of Vulçitrin conducted between 1455 and 1477. The corresponding survey of Vidin was dated 1466, so it can concluded that the survey of Vulçitrin was conducted around that year.

38 In Persian scripts especially the number 5 was signified differently than that in Arabic.

39 Characters became smaller and less clear due to using fewer dots that differentiate a character from another one.

40 According to Inalcık the second defter was either given to the chief accountant or to the provincial governor. İnalcık, Halil, Hicrî 835 Tarihli Sûret-i Defter-i Sancak-ı Arvanid. p. xxi. To see differences between these types of defters compare воА, MAD.d 16 and вОА, тт.d 1081/1 which are two icmal defters of Vulçitrin from the same survey. 
while one of them was utilized to track timars. Ícmals were intensively used for tracking timars up until the end of the reign of Mehmed II (1444-1446, 1451-1481). ${ }^{41}$ During the reign of Beyazid II, in comparison to the preceding period the notes on defters were shorter, and it appears that after the 1480 s the state abandoned the use of icmals for tracking. ${ }^{42}$ It is no coincidence that the earliest extant timar ruznamçe defter was from this period. ${ }^{43}$ This new genre contains only timar transactions implemented in the period between two surveys. These records, as in previous icmals, give information about the passing of a timar from one person to another. However, the novelty in this new type of ledger is that they give details about any addition or subtraction to a timar, the reason why the possessor received the timar, or any dispute concerning a certain timar. That is to say, any simple change related to the possession of a timar began to be tracked much more rigorously and recorded in those defters.

This transformation cannot be handled separately from the well-known reform movement of Mehmed II, carried out in the $1470 \mathrm{os},{ }^{44}$ in which the sultan confiscated many private lands ( $m \ddot{u} l k$ ) and pious foundations ( $v a k l f)$ on behalf of the central treasure and provincial army (timariots). However, a short time later Mehmed II died and his successor Bayezid not only rehabilitated the previous status of many of them ${ }^{45}$ but also tried to erode the power of some of the timar holders. In the ruznamçe defter of 1487-89 we see that many timar holders were dismissed merely because they had enjoyed their timars "for more than three years". ${ }^{46}$ In many cases, however, the reason behind dismissal could

41 For example see BOA, MAD.d 18 (1466) of Vidin and BOA, TT.d 01081/1 (1477) of Vulçitrin.

42 The defters from the reign of Selim I (1512-1520) contain almost no notes. However in one of the defters, which is housed in the Bulgarian National Library "St. Kiril and St. Methodius", from reign of Süleyman I (1520-1566) there are some side notes about transactions. See, Bulgarian National Library "St. Kiril and St. Methodius", MK 26/2 (1526). The icmal defter of Vidin BOA, MAD.d o1 dated 1483 and that of Vulçitrin BOA, TT.d 22 dated 1487 are the defters that contained notes about the timar transactions.

43 The defter catalogued as BOA, MAD.d 17893 is the earliest timar ruznamçe ever known. It contains records from between 1487 and 1489. See, Howard, Douglas A., "The Ottoman Timar System and Its Transformation, 1563-1656", Ph.D. Dissertation, Indiana University, 1987, pp. 48-9.

44 Özel, Oktay, “Limits of the Almighty: Mehmed II's 'land reform' revisited”, Journal of the Economic and Social History of the Orient, 42/2 (1999). pp. 227-8.

45 Özel, “Limits of the Almighty: Mehmed II's 'land reform' revisited”, p. 227.

46 In many records the reasons for the dismissal of timariots were shown as the possession for more than three years "üç yıldan ziyade tasarruf ittügüne şehadet ittükleri sebebden". For example see, BOA, MAD.d 17893, pp. 36-7. In some cases, however, warriors lost their 
be more ambiguous. ${ }^{47}$ In a real sense, this process was nothing but a way of bypassing some timar holders, while in the same source it can be seen that many timars were divided. That is to say, the government either dismissed the targeted timar holders or forced them to accept smaller fiefs.

In Ottoman history, such a purge was not the usual practice. Previous defters indicate that timar holders used to be dismissed for being involved in criminal activities, for absenting themselves from military operations, or for attempting to defraud the authorities in relation to timar revenues. ${ }^{48}$ Therefore, this change during the reign of Bayezid can be interpreted as a counter reform against Mehmed's confiscation activity on behalf of the timar holders. Free land owners and supervisors of religious endowments not only attempted to restore their privileges but also led Bayezid II to weaken the timar holders. The year 1487 seems to have been a turning point in that the first ruznamçe defter was actually evidence of empire wide inspection. This ruznamçe contains only sancaks in Anatolia. As Douglas Howard has claimed, we can estimate that there was another ruznamçe prepared in the same year, which contained information about the sancaks in the Balkans. ${ }^{49}$ There is a sign of this implementation in the icmal defter of Vulçitrin of the same year. ${ }^{50}$ Moreover, that counter-reform was probably carried out throughout Beyazid II's reign. For instance, another ruznamçe defter surviving from his reign, containing timar transactions from 1498 to 1501 , also mentions such dismissals. ${ }^{51}$

The inspection of 1487 was equivalent in importance to the great inspection launched in $1632 . .^{52}$ Both inspections were arranged to reveal defects in the timar system or to punish some timar holders. After the inspection of

grants under the pretext that they had been in possession for five years, BOA, MAD.d 17893, pp. 24, 26.

47 For example, "mezkur İsmail çokdan tasarruf ider deyü şehadet oldunduğu sebebden..." means, "because it is witnessed that previously mentioned İsmail has occupied [the $t i$ mar] for a long time...", BОA, MAD.d 17893, p. 34.

48 In early icmal defters there are plenty of notes about the reason for the dismissals. See, İnalcık, Hicrî 835 Tarihli Sûret-i Defter-i Sancak-ı Arvanid and İnalcık, Radushev, and Altuğ, 1445 Paşa Livâsı İcmâl Defteri.

49 Howard, "The Ottoman Timar System and Its Transformation, $1563-1656$ ", p. 49.

5o In this defter it can be seen that there are some notes added in the same years saying the timar holder was dismissed because he had occupied the timar for a long period. See, вОА, тт.d 22, pp. 73, 76, 84, 86, 92.

51 ївАК, MC.YZ.O. 82 .

$5^{2}$ In the seventeenth century, due to a wide discontent about "degeneration" of the timar system, in 1632 the government decided to scrutinize the timar possessors. 
1632, the content of the ruznamçe defters radically changed. For example, post-inspection defters began to include physical descriptions of timar holders, which had not previously been the case. Likewise, after 1487 the content of icmal defters began to change. Compared to previous defters, later ledgers became more limited, containing fewer details and the side notes giving information about the future of transaction of timars almost disappeared. As cebe defters were emerged with the inspection of 1632 , the inspection of 1487 gave birth to the ruznamçe defters. It is a basic characteristic of ruznamçe defters beginning in $1498^{53}$ that each sancak was recorded in a different section; however, the first ruznamçe seems to be premature in terms of format, in that each timar record was registered in the defter chronologically. Sancaks were recorded in a mixed way, which means that they were very unsuitable for timar tracking. ${ }^{54}$ It seems that the Ottoman scribes realized this earlier on, so they began to organize the succeeding ruznamçes in sancak-base sections.

\section{Value-Oriented Timar}

It is conventionally accepted by Ottomanists that there were three kinds of grants in the timar system, which were timar, zeamet and hass. Grants yielding revenue worth from 20,000 akçes to 100,000 akçes were called zeamet; grants lower than zeamet were labelled timar, and those higher were called hass. However, these scholars could not explain why, occasionally, in some defters some livelihoods above 20,000 akçes were called timar whereas others below that level were referred to as zeamet. Historians usually explain this as the word timar being used for all kind of grants. ${ }^{55}$ Although this is not wrong, it does not explain the main reason either. As apparent in the examples of landoriented timars above, the value of a timar could fluctuate over time. In such conditions, it would not be possible to make a clear-cut distinction between grant types. Only after grants were designated as fiscal units, or value-oriented, did this classification become crystal clear in the defters.

\footnotetext{
53 ївАК, MC.YZ.O. 82.

54 For example if you want to track a timar from a certain sancak, you have to check out all records one by one since in the first ruznamçe sancaks were recorded in a mixed way. However, in other defters the only thing you need to do is to find the section in which the required sancak was recorded.

55 Kunt, I. Metin, The Sultan's Servants: The Transformation of Ottoman Provincial Government, 1550-1650 (New York: Columbia University Press, 1983), p. 12.
} 
Now the question is whether there was such a classification in the physical timars. First, the term zeamet did not exist in the Ottoman defters until the 1470s. The earliest sources show that the Ottoman incumbents or warriors were bestowed either hass or timar before that era. In fact, rather than the size of grant it was the administrative position that the possessor of the grant occupied that was important in determining whether it was hass or timar. In this early stage, the administrative organization in the regions where the timar system was applied consisted of eyalets, somewhat autonomously governed provinces, which were constituted by livas/sancaks (sub-provinces) with several vilayets or subaşılıks in each. A vilayet, or subaşılık, was a town or fortresscentered area supervised by a warrior called a subaşı (head of soldiers) or zaim (leader or chief). There were two types of subaşılıs, which were differentiated based on the criteria of the presence of a military figure called a serasker or çeribaşı. This term also means head of soldiers, but the serasker was lower ranking than a subaşı. A subaşı would be granted hass if he had a serasker under his command, whereas a subaşı without a serasker held a timar, as did all the other lower-ranking soldiers such as the cavalry sipahis. The central subaşılı of a liva used to be ruled by a sancakbeyi or miralem (lit. lord of the banner), who possessed the largest hass in the liva. Above him there was the governor of the province, called beylerbeyi or mirimiran (lit. lord of the lords), who possessed a hass several times larger than that of sancakbeyi. ${ }^{56}$ Evidently in this initial period the type of grant was closely related to the status of its possessor.

During the reign of Mehmed II vilayet or subaşılık gradually lost its status as an administrative unit. The term nahiye (region) was began to be used instead of vilayet. The economic and administrative power of subaşıs gradually eroded in this period. Finally in the 1470s status of subaşıs was either lowered or their posts were totally abolished. The lands reserved for subaşıs began to be called zeamet and in many cases zeamets were divided into several parts. Subsequently this term gradually began to connote a name of a grant, rather than an administrative unit. Eventually, zeamet as a grant gained its widely-known definition with the reign of Süleyman I (1520-1566). Henceforth, a grant type began to be defined by its monetary capacity.

Another point reflecting this transformation is that, under timar records in the icmal defters of the reign of Mehmed II and Bayezid II, there can be frequently seen the phrase fil-asl, which means "by origin". This phrase disappeared from defters in the following period. Fi'l-asl referred to the value of a certain timar in the previous defter and was sometimes accompanied by either el-ziyade, meaning surplus, or el-noksan, meaning deficit. That is to say, the

$5^{6}$ Soyudoğan, “Reassessing the Timar System: The Case Study of Vidin (1455-1693)", p. $15^{\circ}$. 
Ottoman officials compared the revenue derived from a certain timar in the previous survey with the newly detected value to determine whether the timar was profitable or not. Therefore, although these phrases supplied authorities with a simple method of timar tracking, they were no longer used after the period of Beyazid II. The main reason behind this shift is related to the change in the meaning of the term timar, in that it had begun to be connoting a unit of revenue or simply a salary rather than a land unit.

With this change in the nature of the timar, the borders of timars became more flexible than previously. For example, a timar constituted by villages A, $B$ and $C$ during the earlier survey would probably appear in the later survey as formed by villages $\mathrm{A}, \mathrm{X}$ and $\mathrm{Z}$. In this case, it would be hard to allege that these two units were the same. Therefore, they were no more comparable units. This is why the term fil-asl disappeared from defters.

Table 3 shows a timar recorded in different surveys. It can be seen that the timar originally consisted of three villages. In the period from 1455 to 1487 the border of the timar was fixed. Then after the 1487 survey the border of the $t i$ mar totally changed and each village began to be recorded under different $t i$ mars. Thus, it can no longer be regarded as land oriented. Using icmal defters after the reign of Bayezid II, it is possible to track only villages, not a timar as a whole, because with each survey the villages of a certain timar were regrouped with different villages. For example, tracking the village of Suhodol, it can be seen that it was grouped with different settlements each time after 1487. In 1519 this village was given timar to a certain Ali along with the village of Leşniçe. However in 1526 it was regrouped with another village. Finally, in 1544 Suhodol was regrouped with many villages and given as a hass to the governor of Rumeli. ${ }^{57}$

The fragmentation in physical structure of timar was mainly resulted by government's effort on the one hand to compensate the timar holders' loss due to any decline in production; on the other hand to preclude them to make excessive profit. As it is seen in Table 1 above Doğancı Yusuf's revenue declined from 10,725 akçes to 8,625 akçes between 1455 and 1477. It seems that the government did not take a measure to compensate the deficit. Such problems somehow would be the main concern of the government in the following decades, which led to re-organzing timar as value-oriented. To give a concrete example, İskender, the head of timariots of Vidin, had a timar yielding 15,222 akçes in 1515. During the next survey in 1530 there was a significant decline in taxes of Village of Kuçofçe and also he lost his right to collect the fees of Voynuks. The state added to his timar some new villages to assure his vested right 
TABLE 3 Transformation of a Timar in Vulchtirin from 1455 to 1526.

\begin{tabular}{|c|c|c|c|c|c|c|c|}
\hline & Hüseyin & $?$ & $\begin{array}{l}\text { Hamza \& } \\
\text { Mustafa }\end{array}$ & $\begin{array}{l}\text { Mustafa \& } \\
\text { Dimitri }\end{array}$ & $\begin{array}{l}\text { Mehmedi \& } \\
\text { Hamza }\end{array}$ & Ali & Abdi \\
\hline & $1455^{58}$ & $1466 ?^{59}$ & $1477^{60}$ & $1485^{61}$ & $1487^{62}$ & $1519^{63}$ & $15^{26^{64}}$ \\
\hline Village of Brestiye & 4,232 & $?$ & 3,239 & 2,816 & 3,172 & $\mathrm{X}$ & $\mathrm{X}$ \\
\hline Village of Suhodol & 3,276 & $?$ & 2,359 & 2,643 & 2,553 & 2,491 & 2,047 \\
\hline Village of Halda & 2,724 & $?$ & 2,189 & 2,636 & 3,606 & $\mathrm{X}$ & $\mathrm{X}$ \\
\hline Village of Leşniçe & & & & & & 2,134 & $\mathrm{X}$ \\
\hline Mezra'a of Bugik & & & & & & & 240 \\
\hline Total & $10,23^{2}$ & 7,002 & 7,787 & 8,095 & 9,331 & 4,625 & 2,287 \\
\hline
\end{tabular}

TABLE 4 Timar of Serasker İskender in 1515 and 1531.

\begin{tabular}{lrll}
\hline $\mathbf{1 5 1 5}$ & \multicolumn{1}{c}{$\mathbf{1 5 3}^{\mathbf{6 5}}$} \\
\hline Village of Kuçofçe & 7,090 & Village of Kuçofçe & 5,889 \\
Village of Kirçurofçe & 3,085 & Village of Kirçurofçe & 4,304 \\
Village of Ravlofçe & 947 & Mezra'a of Kravun & 250 \\
Mezra'a of Gurgu[f]çe & 100 & Mezra'a of Gurgufçe & 100 \\
Resm-i Voynugan-ı Vidin & 4,000 & Village of Krivodol & 2,500 \\
& & Village of Kotluyofçe & 2,400 \\
Yekun (Total) & & Village of Ofçi Brod & 1,519 \\
& $\mathbf{1 5 , 2 2 2}$ & Yekun & $\mathbf{1 6 , 9 5 8}[\mathbf{1 6 , 9 6 2}]$ \\
& & Bervech-i bedel & 17,222
\end{tabular}

58 This timar was previously possessed by Mustafa. During the survey of 1455 it was bestowed on Hüseyin who was one of the servants of sultan. воА, тт.d 2M, p. 299.

59 There is no defter of this survey. Yet the defter of 1485 reveals the total amount of the timar during that survey. BOA, MAD.d 16 (icmal) (Vulçitrin), p. 41b.

6o BOA, MAD.d 16, p. 41 b.

61 BOA, MAD.d 97, p. $5^{8}$.

62 BOA, TT.d 22, p. 72.

63 BOА, тT.d 977, p. 145.

64 BОА, тT.d 133, pp. 366.

65 BOA, MAD.d 70 (icmal) (Vulçitrin), p. 16B.

66 воА, тт.d 16o (icmal) (Vulçitrin), p. 20. 
of a 15,222 akçe salary and also to meet the 2,000 akçes increase in his salary. His current timar was now only 260 akçes less than his actual salary. By noting his actual salary $(17,222$ akçes) the state in fact gave the timar holder a kind of promise that his salary would be increased to that amount as soon as finding new resources.

The process of the abstraction of timars or the fragmentation of physical timars become possible by virtue of jurisdictional revolution or modernization of bureaucracy in a Weberian ${ }^{67}$ sense, that took place between the $1470 \mathrm{os}$ and 1520s. In this period, the previous traditional regulations were systematically codified to construct bureaucratic or administrative standardization in terms of punishments, taxes and fees, salaries of state personnel and protocols clarifying the place of individuals occupying positions in the hierarchal organization of the bureaucracy. In particular, a law code attributed to the period of Mehmed II's rule, ${ }^{68}$ which was further developed during the reign of Bayezid II, standardized the hierarchical organization of statesmen and all other bureaucratic and military staff. By the time of Süleyman standardization and

67 Several characteristics of modern bureaucracy in Weberian thought are the standardization of rules and regulations, hierarchical organization of staff, filing and specialization. Weber, Max, From Max Weber: Essays in Sociology, tr. H.H. Greth and C. Wright Mills (New York: Oxford University Press, 1946), pp. 196-8.

68 There has been a discussion of the authenticity of the law enacted by Mehmed II. While some historians claim that it was written in a period after Mehmed II, others are certain about its authenticity. Özcan, Abdülkadir, Fatih Sultan Mehmed: Atam Dedem KanunuKanunnâme-i Âl-i Osman (İstanbul: Yitik Hazine, 2012), pp. xi-xii; Akgündüz, Ahmet, Osmanlı Kanunnâmeleri ve Hukukî Tahlilleri, 2nd ed. (İstanbul: Osmanlı Araştırmaları Vakfi, 2006), vol. I, pp. 311-12. Probably this law was partly changed when copied in a later period. In this law the word zeamet was used in some articles as a type of grant yielding over 20,00o akçes. Özcan, Fatih Sultan Mehmed: Atam Dedem Kanunu-Kanunnâme-i $\hat{A} l-i$ Osman, pp. 12-13. However, in this period it is hard to say that Ottomans used this term to mean a type of grant, rather, it was still being used in meaning of administrative unit, as used in another article in the same law, Özcan, Faih Sultan Mehmed:Atam Dedem Kanunu-Kanunnâme-i Âl-i Osman, p. 14. For example, in the defter of Vulçitrin dated 1477, the word zeamet is always used in reference to a subaşılı. The records of zeamets in this period appeared as; "Zeamet-i Morava, zaimeş Illyas Bey veled-i Malkoç", which can be interpreted as the zeamet of Morava region being possessed by Illyas the commander. BОA, MAD.d 16, p. 43. In other examples in the same defter three timars were recorded with notes such as "timar-i $X$, ze'âmet tarikiyle tasarruf eder" which can be translated as the timar of X person that was possessed by means of ze'âmet. BOA-MAD.d 16, pp. 36, 37 and 38. The word zeamet in these examples does not refer to the classical subaşılık but neither does it exactly refer to a type of grant, because they were all recorded as timars. 
codification were so developed that each sancak had its own laws and standards (kanunname), which led to Süleyman being known as "the lawgiver".69

No standardization in the hierarchical organization of incumbents could be possible without the same standardization in their salaries. This point turned the timar, previously designated as a land unit, into a fiscal unit. As shown in the examples above under the topic of land-oriented timars, the amount of revenue the same possessor received might rise or fall according to social and environmental changes. Under such conditions it is not possible to consider that there was a standard salary of the timar possessor. For example, the rapid decline in population and production in Vidin in 1483 affected the incomes of timar possessors. ${ }^{70}$ Standardization did not develop the control mechanisms over state cadres but created a kind of insurance for people to keep their salary at or above a bottom line that was called the kulıç timar (lit. timar of the sword), its core value. Regardless of their size, every grant consisted of two parts: the core value $(k \iota l \iota c ̧)$ and the supplement (hisse, lit. share). In this period what made a timar as a separate unit was its core value not its geographical border.

As can be seen in the table below, the values of grants were divided into several intervals. The minimum value in the interval was accepted as its core value, and any amount, even a single $a k c ̧ e$, over that value was accepted as the supplement. This meant that a timar could be divided without touching its core value. For instance, suppose there was a timar yielding 4,570 akçes. 3,000 akçes represent the core value of this timar, which normally was not allowed to be fragmented. ${ }^{71}$ If this timar was bestowed on a warrior who merited 3,000 akçes, the remaining 1,570 a kçes could be divided into pieces, or kept as a whole, to add to the timars of others.

Reorganizing timars this way made the process of timar bestowals and promotions revolutionary systematic. Depending on his professional or social status, a person on his first bestowal received an initial timar (ibtida timar), which more or less referred to the core value. As long as he served the state, he would receive promotions reserved from the supplements of timars. If in a sancak there were not enough supplements, the state could compensate for this by

69 For an overview of this process see, İnalcık, Halil, "Suleiman the Lawgiver and Ottoman law", Archivum Ottomanicum, I (1969), 105-38.

70 Soyudoğan, "Reassessing the Timar System: The Case Study of Vidin (1455-1693)", pp. $183-4$.

71 Occasionally core values were also temporarily fragmented. In such cases a note was added such as "kılıç timar bozulmamak üzere" which means without breaking core value. This note implied that the fragmentation was temporal. Usually these fragmentations reunited during the next bestowal. 


\begin{tabular}{llll} 
Grant type & Value of grant & Core value & Supplement \\
\hline Timar & & & \\
Timar & $-2,999$ & Whole timar & Whole timar \\
Timar & $3,000-5,999$ & 3,000 & $0-2,999$ \\
Zeamet $^{7}$ & $6,000-19,999$ & 6,000 & $0-13,999$ \\
Hass $^{74}$ & $20,000-99,999+$ & 20,000 & $0-79,999+^{73}$ \\
& $100,000+$ & fixed to position & fixed to position
\end{tabular}

72 Usually timars below 3,00o akçes were bestowed on fortress guards (mustahfiz). What is referred to in this table, however, are not those of guards but timars enjoyed by timariots (cavalry). In some cases we can see that a whole timar below 3,000 was added to another grant and in some cases possessors of such timars kept their timars and received supplements.

73 It became a cliché to define zeamet as a grant with an annual value from 20,00o up to 99,999 akçes. In fact, as Géza Dávid pointed out there were examples of zeamets that exceeded 100,000 a kçes. Dávid, Géza, “Assigning a ze'âmet in the $16^{\text {th }}$ century: revenue-limits and office-holding”, in Dávid, Géza, Studies in Demographic and Administrative History of Ottoman Hungary (Istanbul: IsIs Press, 1997), pp. 215-23. However, the question here is that if the value is important to define a grant then why a zeamet exceeding 100,000 was not called hass. Dávid answered this question by implying that there were two groups of zeamets, a group "could be attached to specific offices independently of their income". So even if they exceeded the limit they were still called zeamet, p. 55. As a matter of fact none of the law codes says that zeamets had upper limit, nor say a hass could be set at least 100,000 a kçes. Yet de facto a hass usually did not drop down below that point while zeamet did not exceed it. From my observations I can say that in Vidin, for example, in 1595 for the first time we see a zeamet exceed the limit. Abdullah bin İbrahim bin Mehmed Paşa (mütefrerrika-i divan-i hümayun) had already been granted 210,783 akçes out of 218,430 akçes. вОA, DFE.Rz.d 166 (timar ruznamçe), pp. 193-4. After that such zeamets began to be seen more frequently in Vidin. Likewise in the sancak of Birecik in the period between 1583 and 1659, it was in 1595 when for the first time a zeamet exceed the limit. BОA, DFE.RZ.d 171 (timar ruznamçe), pp. 890-5. However that phenomenon did not become so common in this region in the following years. Though he does not gaive all the dates it seems that most of the cases that Géza Dávid used in his article were also dated 1595 and after. Therefore we can conclude that one possible reason behind such grants was economic deprivation. As the economic situation went bad such grants become more apparent. Secondly, even if there was such a numerical line between zeamet and hass there would be still another obstacle in that each grant type supplied its possessor with some privileges and duties. Lastly, it seems that it was not because some zeamets were attached to some offices as Dávid argued but it were hasses that were attached to specific offices. A hass was a special type of grant. The core value of each of them was unique. See also footnote below. 
extracting revenue (ifraz) from state lands (hass-ipadişah) or by granting some supplements from another sancak. Alternatively, the timar possessor could request his dismissal ( $\mathrm{mazul}$ ) to receive a higher core-valued timar. Under such circumstances, he had to hand his timar back because legally a person could possess only one core value. In this sense, a core value also referred to a post in the military or the bureaucratic structure. Although a single person was not allowed to occupy more than one post, a post could be occupied by two or more people. Thanks to that, the number of timar possessors would be equal to or more than the number of timars in a region. In other words, the state could assure itself of the presence of a minimum number of military forces in a region. Lastly, such an organization brought about a systematic rotation in attending military campaigns. There are examples in which warriors possessing a grant over 3,00o akçes were called to serve in a military campaign while those who had lower grant were ordered to stay in their sancak to protect it in case of enemy assaults or rebellions. ${ }^{75}$

This reasonably designed system created a serve-and-win mechanism, which operated as long as the state was able to find new economic resources and fulfill the demand for timars and promotions. If the state could not satisfy the demand of people for timars, it would probably not be possible to find sufficient volunteers (serdengeçti / gönüllü) to fight to defend the borders of the empire. On the other hand, this was a self-exhausting system because in order to satisfy the demands for more timars the state had to find new resources, and to find new resources the state needed more soldiers. Actually, the size of both the central and provincial armies had grown, parallel to the successful years of expansion from 1450 s to 1560 , and this was also accompanied by an enlargement of the bureaucracy. This resulted in the number of warrior-officials exceeding a level that could be afforded in the timar system. The abstraction of timars was one of the results of that imbalance, because with redesignation of timars it seems that the purpose of the state was actually to reduce the amount of grants per person. Comparing the average value of a timar in the

74 That is true that a hass was usually above 100,000 akçes and its possessor could receive vacant timars or zeamets as promotions. However, in fact the value of hasses was more or less fixed. If it was decided to bestow a promotion on a statesman he would be dismissed from his current grant to receive a higher one. That is, the grant was directly related the possessor's own title or position. For example, a sancakbeyi enjoying 300,000 akçes could be promoted to a sancak with a hass of 400,000 akçes or would receive at least a one million akçes yielding grant if he had the title of vezir. That is, it is hard to describe hass as having a specific core value.

75 For example see, Miroğlu, İsmet, “49 Numaralı Mühimme Defteri”, Master's Dissertation, Istanbul University, 1996, p. 137/300. 


\begin{tabular}{lll}
\hline & $\mathbf{1 4 5 0 - 1 4 8 7 ^ { 7 6 }}$ & $\mathbf{1 4 1 5 ^ { - 1 4 4 5 }}$ \\
\hline Vulçitrin & 5,092 & 4,497 \\
Vidin & $4,798^{77}$ & 4,924 \\
\end{tabular}

fifteenth century with the value in the sixteenth century a noticeable decline can be observed. Despite this, the state was obliged to fulfill every demand for timars or promotions. To resolve the problem the state created a kind of debt system. If a volunteer somehow could get a timar, to keep it he had to undertake service in military operations as required. Fulfilling this military duty gave him the chance to receive promotion in terms of his timar. Since the state was not able to find the extra revenues, promotions were recorded, to be allotted in the future (ber vech-i tekmil/ber vech-i iltizam/ber vech-i emr/ber vech-i bedel). In most cases, however, those possessing timars never received a promotion in their lifetime or, by the time they were given a promotion, the timariot had already undertaken another period of military service and was entitled to a further promotion. Indeed, it was practically impossible to manage this endless serve-and-win cycle.

As a result of the transformations in the timar system, the bureaucratic burden dramatically increased. A highly specialized group of accountants were employed in an office called the defterhane-i amire, which was responsible for conducting surveys in certain periods and processing many timar transactions every day. As a result of the standardization and codification movement in the Ottoman empire, all kinds of state revenues and expenses began to be studiously calculated and each type of salary could be converted to another based on fixed rates. For example, if a janissary wished to receive a timar instead of his ulufe he would receive a timar according to the formula that two-thirds of the ulufe would be multiplied by one thousand $\left(\right.$ timar $=\frac{2}{3} \times$ ulufe $\left.\times 1,000\right) .78$ Furthermore, the conditions under which a timar possessor would receive an

${ }_{7} 6$ The values in this period were, in reality, far higher than the data in the table. In this period some small timars below 1,00o akçes were sometimes bestowed on more than ten non-Muslim warriors. It is due to such timars that the average value is reflected below the actual value.

77 In this period Vidin was attacked and pillaged several times, which reduced the productivity potential of timars.

78 For details of such conversation methods see, Soyudoğan, "Reassessing the Timar System: The Case Study of Vidin (1455-1693)", pp. 24-9. 
amount of promotion was fixed. For instance, if when a sultan come to the throne a timar possessor or a warrior proved his successes in battlefield by bringing a certain amount of enemy heads, then the timar possessor would receive a promotion of ten to 20 percent for every 1,000 akçes of his timar..$^{79}$ With a new regulation issued in 1531 the burden of the defterhane-i amire increased by limiting the authority of provincial governors in terms of timar bestowals. From this time, these governors could only bestow timars below 3,000 akçes (tezkiresiz timar). ${ }^{80}$ Lastly, the defterhane-i amire was responsible for tracking timars to prevent timar fragmentations and any kind of malpractice in timar bestowals.

With these changes the question arises as to how Ottoman officials tracked timar revenues. The logic behind the new tracking method was that once a survey was conducted, the timar as a unit of revenue was not updated until a new survey. In a way, timar had turned into an abstract value, which had no necessary correlation with the actual value. The problem in this method was that the more expanded the period between two surveys the less relevant was the timar in terms of its actual value. In particular, when the Ottoman state stopped surveying after the 1580 s in these regions (Vidin and Vulchitrin) timars became nothing but irrational entities. Examination of the example given below shows that nothing other than the possessor of the timar changed over a century. Even supposing that in the last survey of Vidin in 1579 this timar was accurately surveyed, so that the recorded revenue was an actual value, it would be impossible for the value of the timar to have remained the same for a century.

According to these records, this timar was passed from one person to another without fragmenting until 1622 when it was divided into two shares. According to the law, the core value of this timar should have been 6,00o, but it was divided into two shares lower than that amount. Each time it was noted that it was shared without breaking the core value. However, after 1622 it became a kind of family property: Hasan left his share of 3,00o akçes to his son Hasan, and Zülfikar left his share of 4,00o akçes to his son Hızır. The story of this timar shows that if someone at the end of seventeenth century was still seeking a timar that was surveyed a century earlier, there must have been some economic rationale, i.e. an economic value, but this had nothing to do with these recorded amounts, which were nothing but virtual references to real wages that remained unclear. Therefore, such repetition of values in the records had

79 Soyudoğan, "Reassessing the Timar System: The Case Study of Vidin (1455-1693)", pp. 33-4.

80 Afyoncu, Erhan, "Osmanlı Devlet Teşkilatında Defterhâne-i Âmire”, Ph.D. Dissertation, Marmara University 1997. pp. 7-8. 
TABLE 7 Transformation of a Timar in Vidin from 1580 to 1692.

\begin{tabular}{|c|c|c|c|c|c|c|c|}
\hline & \multirow{2}{*}{$\begin{array}{l}\text { Ahmed bin } \\
\text { Ferhad }\end{array}$} & \multirow{2}{*}{$\begin{array}{l}\text { Osman bin } \\
\text { Hamza }\end{array}$} & \multirow[t]{2}{*}{ İbrahim } & \multicolumn{2}{|c|}{ 1-Hasan bin İbrahim } & \multicolumn{2}{|c|}{ 1-Hasan bin Hasan } \\
\hline & & & & 2-Mehmed & 2-Zülfikar & 2-Hızır & ülfikar \\
\hline & $15^{80^{81}}$ & $1598^{82}$ & $1618^{83}$ & $1622^{84}$ & $163^{85}$ & $1664^{86}$ & $1692^{87}$ \\
\hline Village of Periş & 5,000 & 5,000 & 5,000 & 5,000 & 5,000 & 5,000 & 5,000 \\
\hline $\begin{array}{l}\text { Village of } \\
\text { Drajinçe }\end{array}$ & 2,000 & 2,000 & 2,000 & 2,000 & 2,000 & 2,000 & 2,000 \\
\hline Total & $7, \mathbf{0 o 0}$ & 7,000 & 7,000 & 7,000 & $7, \mathbf{0 o 0}$ & $7, \mathbf{0 0 0}$ & 7,000 \\
\hline Share 1 & & & & 3,000 & 3,000 & 3,000 & 3,000 \\
\hline Share 2 & & & & 4,000 & 4,000 & 4,000 & 4,000 \\
\hline
\end{tabular}

the practical effect that allowed officials to better track timars, but limited the state's control over the economic resources. That was the Ottoman paradox of centralization.

\section{Conclusion}

The common way of defining and describing the timar system has given the perception as if it came into existence at the initial period of the formation of the Ottoman state at the beginning of the fourteenth century and remained inert until the end of the sixteenth century. Closer analysis shows that the timar system underwent a serious transformation in the period from 1487 to 1530 , through which it became both more centralized and more fragile.

The conceptualization of "abstraction of timars", the transformation of the timar from a physical being into a fiscal entity, in fact reflects the desire of the Ottoman state for centralization. That propensity was an Ottoman reality even from the period when the Ottoman empire was still a small chiefdom. Osman,

\footnotetext{
81 Tapu ve Kadastro Arşivi, TT 219, p. 45b.

$82 \quad$ BOA, DFE.RZ.d 214 (timar ruznamçe), p. 270.

83 BOA, MAD.d 107 (timar ruznamçe), p. 420.

84 BOA, DFE.RZ.d 411 (timar ruznamçe), p. 477, 506.

85 BOA, DFE.RZ.d 498 (timar ruznamçe), p. 160.

86 BOA, DFE.RZ.d 777 (timar ruznamçe), p. 189.

87 BOA, MAD.d 83, p. 126, 128.
} 
the eponymous founder of the Ottoman dynasty, according to legend, killed his uncle, and Osman's sons followed that tradition of killing members of the Ottoman family who had the potential to claim the throne. On the one hand this struggle in the Ottoman family, and on the other hand the fight against external powers, made inevitable the presence of autonomous power holders together with the Ottoman family in the empire. At the beginning there were traditional Turkic tribal warlords $(a l p)$, who were gradually replaced by the newly emerging Muslim and Christian elites (uçbeyi). In the first one-and-ahalf centuries these elites were ruling somewhat autonomous polities called il or vilayet. Such autonomy brought about their control over the economic resources from vast territories. ${ }^{88}$ Thus, the land-oriented timars were closely linked to the presence of such autonomous warlords.

The desire to move towards centralization was not only an in-family affair for the Ottoman dynasty; it was also crucial to strengthen the central power forces as a counterbalance against those centrifugal dynasties. For this purpose, the ruling Ottoman family not only invested in a central army (especially the janissaries), but also tried every avenue to erode centrifugal powers. From the very earliest defters in the 1430 s to the end of 1470 s it can easily be observed that the state systematically replaced the timar possessors who were men of the provincial lords with those chosen by the sultan (gulam-ı mir). ${ }^{89}$ Losing their armed men first eliminated the relatively weaker subaşıs who ruled over different regions of a sancak. Beginning with 1470 os these figures were gradually replaced by ordinary zaims, who were usually chosen from the central cadres, and reorganized, as other timar-possessor cavalries, under the authority of an alaybegi or miralay. This means that they lost their administrative authority. On the other hand the greater lords, who especially ruled over the frontier sancaks, usually in a hereditary manner, were dealt the final blow by shortening their service period with imposing one-year contracts in the 1550 . That is, one person could govern a province (eyalet) or a sub-province (liva) only for one year. After that period either his contract was extended or he would appointed to somewhere else. Thus, none of governors would stay enough in a place to form an economic and military power against the center. Lastly, another measure was taken in that sense by limiting the authority of provincial governors over timar bestowal. It was necessary for governors to ask for permission (tezkire) in the cases of bestowing a grant over a certain amount.

88 BOA, MAD.d 544 .

89 This term can be seen almost in all defters prior to 1480 . Besides the men of the central cadres, recorded as, gulam-ı X Paşa, were also often granted timars in this period. Furthermore, many janissaries and other members of the central army also received timars. 
All these tendencies towards centralization ended with the reform of the bureaucracy in a more rationally and centrally organized way. This renovation brought about a change in the timar system, in the sense that both that the provincial administration and timar control mechanism were changed, and that the timar itself no longer connoted a land unit but now represented a fiscal unit, i.e it was reduced to calculable, abstract values. As a result of these changes, the Ottoman empire became one of the most centralized and disciplined states of the premodern period. However, at the same time the system ironically became more fragile due to a phenomenon which Geroge Ritzer calls "the irrationality of rationality". ${ }^{90}$ As the means of central control developed, the efficiency and the controllability of the system declined, since timars came to serve a kind of fiat money that did not match up to any real production. In this condition possessors became less attached to a certain land demarcated by timars as had been case before. Instead, they began to overenthusiastically seek higher value timars or vacant timars in order to have another slice of the profit, which eventually resulted in fraud and nepotism. In addition, the continuous displacements of provincial warriors from one timar to another and administrators from one sancak to another alienated them from their duties. That paradoxical essence of the centralization undermined the very basis of the timar system if not that of the whole society.

9o Ritzer, George, The McDonaldization of Society, 8th ed. (Los Angeles: Sage Publications, 2015). p. 132 . 